\title{
PERAN KEPALA SEKOLAH DALAM MENINGKATKAN KEDISIPLINAN GURU DI SMP ISLAM PLUS DARUL HUKUMAINI JONGGAT
}

\author{
Lalu Fauzi Haryadi, Safinah \\ Dosen Tetap IAI Hamzanwadi NW Lombok Timur \\ Email: lalufauziharyadi75@gmail.com
}

\begin{abstract}
Abstrak: Penelitian ini adalah untuk mengetahui Peran kepala sekolah dalam meningkatkan kedisiplin guru pada masa pandemik covid-19 dan bagaimana kendala yang dihadapi oleh kepala sekolah dalam meningkatkan kedisiplin guru di SMP Islam Plus Darul Hukumaini Jonggat Kecamatan Jonggat Kabupaten Lombok Tengah Tahun. Penelitian ini menggunakan penelitian kualitatif deskriptif yaitu untuk mendeskripsikan peran kepala sekolah dalam meningkatkan kedisiplin guru. Teknik pengumpulan data dilakukan dengan wawancara dan observasi. Adapun wawancara dilakukan dengan metode wawancara terstruktur kepada narasumber yaitu guru dan kepala sekolah, observasi untuk melihat kegiatan-kegiatan yang dilakukan oleh guru sebagai data pendukung dari hasil wawancara. Sedangkan teknik analisis data dengan reduksi data, display data, dan verifikasi data. Hasil penelitian menunjukkan bahwa kedisiplinan guru di SMP Islam Plus Darul Hukumaini Jonggat sudah cukup baik namun masih tetap perlu diadakan upaya peningkatan karena berbagai pelanggaran tata tertib guru/protocol kesehatan kerap kali terjadi. Sedangkan faktor pendukung kepala sekolah yakni prasarana sekolah, peraturan sekolah yang akuntabel, dan lingkungan sekolah.
\end{abstract}

\section{Kata kunci: Kepala Sekolah, Kedisiplinan Guru}

Abstract: This study was to determine the role of school principals in improving teacher discipline during the COVID-19 pandemic and how the obstacles faced by school principals in improving teacher discipline at SMP Islam Plus Darul Hukumaini Jonggat, Jonggat District, Central Lombok Regency. This study uses descriptive qualitative research to describe the role of the principal in improving teacher discipline. Data collection techniques were carried out by interview and observation. The interviews were conducted using a structured interview method to the resource persons, namely teachers and school principals, observations to see the activities carried out by teachers as supporting data from the results of the interviews. While the data analysis techniques with data reduction, data display, and data verification. The results showed that the discipline of teachers at SMP Islam Plus Darul Hukumaini Jonggat was quite good but efforts still needed to be made because various violations of teacher rules/health protocols often occurred. While the supporting factors for the principal are school infrastructure, accountable school regulations, and the school environment.

Keywords: Headmaster, Teacher Discipline 


\section{PEDAHULUAN}

Kepala sekolah adalah pemimpin sebuah lembaga pendidikan formal yang bertanggung jawab terhadap kelansungan belajar mengajar, serta mengembangkan potensi yang ada pada lembaga yang dipimpinnya. Pandemi covid-19 yang berkepanjangan sampai saat ini, menguras banyak ide-ide kreatif dan inovatif sosok kepala sekolah demi berlangsungnya pembelajaran yang efektik. Sekolah mengalami banyak kesulitan dengan datangnya pandemi covid-19 seperti harus menerapkan protokol kesehatan yang ketat di sekolah, belajar dari rumah dan juga pembelajaran jarak jauh (daring dan luring). Kesulitan tersebut menimbulkan masalah baru bagi lembaga pendidikan yaitu: keterbatasan teknologi informasi oleh guru dan sisiwa, sarana dan prasarana yang kurang memadai, akses internet yang terbatas, dan kurang siapnya penyediaan anggaran (Aji, 2020:398). Sehingga ada dua solusi yang bisa ditawarkan yaitu, solusi langsung yang berupa kebijakan dari lembaga pendidikan atau sekolah dan solusi tidak langsung yang berupa kebijakan dari pemerintah setempat (Amalia \& Sa'adah, 2021:214)

Solusi langsung lembaga pendidikan yang menyelenggarakan pendidikan tatap muka di masa pandemi covid-19 saat ini harus mengikuti protokol kesehatan yang sangat ketat, seperti menggunakan masker, mencuci tangan, dan menjaga jarak. Peran kepala sekolah sangat urgen dalam kondisi seperti ini, harus menerapkan kedisiplinan penuh terhadap guru dan siswanya. Peranan kepala sekolah harus menunjukkan sikap persuasif dan keteladanan sehingga dapat menjadi contoh terhadap disiplin kinerja guru. Kepala sekolah yang tidak mau mendengar pendapat bawahan menyebabkan guru bertindak apriori terhadap kepentingan pekerjaan atau sekolah. Hal ini akan menurunkan disiplin kerja guru (Juliana, 2014: 3).

Kepala sekolah memiliki peran yang sangat penting, menurut Mulyasa (2007) dalam Handayani (Yani, 2014:179) yaitu: 1) educator (pendidik): Kepala Sekolah harus senantiasa berupaya meningkatkan kualitas pembelajaran yang dilakukan oleh para guru. 2) Manager: Kepala Sekolah harus memiliki strategi yang tepat untuk memberdayakan tenaga kependidikan melalui kerjasama atau kooperatif, memberi kesempatan kepada para tenaga kependidikan untuk meningkatkan profesinya, dan mendorong kelibatan seluruh tenaga kependidikan dalam berbagai kegiatan menunjang program sekolah. 3) Administrator. Kepala Sekolah sebagai administrator memiliki hubungan yang sangat erat dengan berbagai aktifitas pengelolaan administrasi yang bersifat pencatatan, penyusunan dan pendokumenan seluruh program sekolah. 4) Supervisior: Kepala Sekolah yaitu melakukan pengawasan dan pengendalian untuk meningkatkan kinerja tenaga pendidikan. Kemampuan supervisi Kepala Sekolah dapa diwujudkan dengan penyusunan program supervisi kelas, pengembangan program supervisi kegiatan ekstrakulikuler, perpustakaan, laboratorium, dan ujian. 5) Leader : Tugas Kepala Sekolah sebagai leader harus mampu memberikan petunjuk dan pengawasan, meningkatkan kemampuan tenaga kependidikan, membuka komunikasi dua arah, dan mendelegasikan tugas. 6) Innovator: Kepala Sekolah sebagai inovator akan tercermin dari cara-cara yang dilakukan pekerjaannya secara kontrukstif, kreatif, delegatif, integrative, rasional dan objektif, pragmatis, keteladanan, disiplin, adaptabel dan fleksibel. 7) Motivator: Motivasi ini dapat ditumbuhkan melalui pengaturan lingkungan fisik, pengaturan suasana kinerja, disiplin, dorongan, pengahargaan secara efektif, dan penyediaan berbagai sumber belajar melalui pengembangan Pusat Sumber Belajar.

Peran kepala sekolah menurut lucke dalam (Yuliandri \& Kristiawan, 2017:575) bahwa Kepala sekolah mendorong terwujudnya visi, misi, tujuan dan sasaran sekolah melalui program yang terencana, dan bertahap. Oleh sebab itu kepala sekolah harus menjalankan fungsi-fungsi manajerial seperti perencanaan, pengorganisasian, pengarahan, pemberian 
motivasi, pelaksanaan, pengorganisasian pengendalian, evaluasi dan inovasi. Selain itu Kepala skolah berhak sebagai pengambil kebijaksanaan keputusan tertinggi di sekolah, sekaligus dapat menindak tegas guru yang tidak profesional dan tidak disiplin melaksanakan tugas sesuai dengan tuntutan utama dan kode etik keguruan dalam profesinya sebagai guru. Pengertian kedisiplinan dilihat dari profesi seorang guru adalah sikap dan nilai-nilai di sekolah agar proses belajar mengajar dapat berjalan lancar sesuai dengan tujuan yang hendak dicapai. Selain itu kepala sekolah merupakan pendorong bagi perkembangan dan kemanjuan sekolah serta bertanggung jawab dalam meningkatkan akuntabilitas keberhasilan siswa dan programnya (Fitrah, 2017:27).

Demi terbentuknya kedisiplinan pada guru, kepala sekolah dapat melakukan pembinaan disiplin yaitu dengan memberikan motivasi, keteladanan, dan memperhatikan kesejahteraan guru (Andriyani, 2013:viii). Kepala sekolah sebagai figur yang harus menjadi teladan bagi warga sekolah, dan kepala sekolah sebagai leader harus memberikan petunjuk dan pengawasan, meningkatkan kemauan tenaga kependidikan, membuka komunikasi dua arah (Devi et al., 2019:125) khusunya peran kepala sekolah dalam membetuk kedisiplinan guru.

Kurang disiplinnya guru merupakan bentuk dari rendahnya kinerja guru. sedangkan rendahnya kinerja guru merupakan indikasi dari rendahnya kemampuan kepala sekolah dalam menjalankan perannya sebagai pemimpin pendidikan (Gaol \& Siburian, 2018:67). Hal tersebut tidak hanya berdampak pada guru, akan tetapi berdampak pula pada kedisiplinan peserta didik sebagai generasi penerus bangsa. Guru dan karyawan harus memberikan contoh yang baik untuk siswanya, salah satunya dengan menegakkan kedisiplinan di sekolah dengan mengikuti seluruh rangkaian peraturan dan tata tertib yang telah ditetapkan. Menanamkan nilai-nilai bahwa pelanggaran atau penyimpangan dari tata tertib itu akan merugikan dirinya dan bahkan dapat ditindak dengan mendapat sanksi atau hukuman. Kedisiplinan guru dapat diukur dari 6 indikator yaitu akseptansi, energi kemauan, bekerja keras, menghargai waktu, mengembangkan produktivitas personal dan persistensi (Nashir, 2016:24). Peningkatan disiplin guru utamanya dimulai dari sekolah, karena pada lingkungan sekolah menunjukkan posisi kepala sekolah sebagai sumber team leader atau manajer sekolah dan sangat penting perananya melalui upaya yang direncanakan secara efektif dan efisien (Uriatman, 2015:823).

Kepemimpinan kepala sekolah di SMP Islam Plus Darul Hukumaini Jonggat dalam meningkatkan kedisiplinan guru masih perlu diperbaiki lagi, karena berdasarkan observasi menunjukkan bahwa kurang mampu menggerakkan dan mengarahkan warga sekolah untuk menegakkan kedisipilinan seperti masih banyak guru yang terlambat datang ke sekolah, ada guru yang sering absen, tidak menggunakan masker, jarang melalukan cuci tangan sebelum masuk kelas. Hal tersebut menunjukkan bahwa kepala sekolah belum sepenuhnya berhasil mempengaruhi pola pikir, cara kerja setiap anggota agar bersifat mandiri dalam bekerja terutama dalam meningkatkan kedisipinan, terlebih lagi kesipilinan guru yang harus menjadi teladan bagi seluruh peserta didiknya.

\section{METODE PENELITIAN}

Sesuai dengan masalah yang dibahas dan memperhatikan tujuan yang ingin dicapai serta manfaatnya, maka pendekatan penelitian yang digunakan adalah pendekatan kualitatif yang bersifat deskriptif. Metode pendekatan kualitatif adalah prosedur penelitian yang menghasilkan data deskriptif berupa kata-kata tertulis atau lisan dari orang- orang dan perilaku yang dapat diamati (Margono, 2009: 36) Sedangkan Penelitian deskriptif yaitu menuturkan dan menafsirkan data yang berkenaan dengan fakta, keadaan, variabel, dan 
fenomena yang terjadi saat penelitian berlangsung dan menyajikannya apa adanya (Sudrajat, 2005: 89).

Tujuan utama penelitian yang dilakukan dengan metode deskriptif ini adalah untuk mendapatkan gambaran tentang gejala atau obyek pada saat penenelitian dilakukan. Gejala atau obyek tersebut dijadikan data untuk kemudian dibahas dan diuraikan. Penelitian dengan pendekatan kualitatif ini memperoleh keterangan-keterangan atau informasi mengenai Peran Kepala Sekolah Dalam Meningkatkan Kinerja Guru Pada Masa Pandemi Covid-19 di SMP Islam Plus Darul Hukumaini.

Teknik pengumpulan data dalam penelitian kualitataif dilakukan dengan observasi, wawancara dan dokumentasi(Sugiyono, 2009). Observasi dilakukan untuk melihat kondisi konkrit di SMP Islam Plus darul Humaini terkait dengan kegiatan-kegiatan guru di sekolah setiap harinya. Wawancara kepada guru dan kepala sekolah untuk mendapatkan informasi mendalam tentang praktik kedisiplinan guru di SMP Islam Plus darul Humaini. Sedangkan teknik analisis data dilakukan dengan reduksi data, display data, dan verifikasi data (Sugiyono, 2009).

Reduksi data pada penelitian ini dilakukan dengan memilih data yang sesuai dengan tema dan fokus penelitian terkait dengan peran kepala sekolah dan kedisiplinan guru di SMP Islam Plus darul Humaini, kemudian peneliti sajikan dalam bentuk deksripsi tentang peran kepala sekolah dan kedisiplinan guru. Agar data yang didapatkan lebih akurat maka peneliti melakukan verifikasi data dengan menyimpulkan sesuai dengan kebutuhan penelitian.

\section{HASIL DAN PEMBAHASAN \\ Peran Kepala Sekolah Dalam Meningkatkan Kedisiplinan Guru di SMP Islam Plus Darul Hukumaini Jonggat}

Peran kepala sekolah selaku pemimpin dalam lembaga pendidikan sangatlah berpengaruh terhadap setiap warga sekolah. Kepala sekolah merupakan pemimpin disuatu sekolah yang bergantung semua keputusan tentang aturan dan tata tertib sekolah. Keputusan yang diambil oleh kepala sekolah sangat mempengaruhi semua kegiatan yang ada pada setiap unit pada sekolah tersebut. Oleh karena itu kedisiplinan yang ada pada kinerja guru dan siswa merupakan pengaruh dari manajemen yang dikelola oleh kepala sekolah pada umumnya.

Peran kepala sekolah dalam meningkatkan kedisiplinan guru Pada Masa Covid-19 di SMP Islam Plus Darul Hukumaini Jonggat adalah kepala sekolah memberikan contoh, motivasi bagi warga sekolah dan menentukan aturan, tata tertib guru dan siswa dalam setiap kegiatan di Sekolah. Menyangkut kedisiplinan guru dan siswa SMP Islam Plus Darul Hukumaini Jonggat sebetulnya sudah bisa dikatakan telah melaksanakan kedisiplinan dengan baik. Sehingga apabila ada guru dan siswa yang tidak disiplin itu hanya sebagian kecil dan hanya guru atau siswa tertentu saja. Dengan kata lain bahwa pelanggaranpelanggaran pada tata tertib ini masih ada namun hanya bersifat pelanggaran kecil.

Upaya yang dilakukan oleh kepala sekolah di SMP Islam Plus Darul Hukumaini Jonggat dalam meningkatkan kedisiplinan guru pada masa Covid-19 sebetulnya dengan satu kali kerja, yakni dengan memperhatikan Protokol kesehatan dan hak para guru, dengan begitu guru akan senantiasa mengajar dengan disiplin dan semangat. Semngat para guru mengajar dan memberikan contoh yang baik tentang kedisiplinan kepada siswa, secara otomatis siswa juga akan menjaga kedisiplinan sekolah. Tidak hanya itu, kepala sekolah juga memberikan peraturan yang harus ditepati oleh siswa dan mendapatkan hukuman bagi siswa yang melanggarnya. 
Salah satu kegiatan disiplin yang dilakukan di SMP Islam Plus Darul Hukumaini Jonggat adalah setiap 15 menit sebelum kegiatan belajar mengajar dimulai, Cuci Tangan sebelum masuk kelas dan memakai masker didalam kelas. Hal tersebut merupakan kebijakan kepala sekolah untuk seluruh warga sekolah di SMP Islam Plus Darul Hukumaini Jonggat yang dilakukan dalam bentuk pemberian motivasi dan contoh kepada para guru dan siswa agar menjalani kebijakan tersebut secara disiplin.

Kepala sekolah SMP Islam Plus Darul Hukumaini Jonggat memiliki aturan sekolah yang telah ditulis pada tata tertib sekolah, sehingga guru dan siswa terjaga dari pelanggaran yang besar yang bisa mencoreng nama baik sekolah dan orang tua. Hal ini menunjukkan bahwa kedisiplinan guru dan siswa di sekolah SMP Islam Plus Darul Hukumaini Jonggat tergolong baik walaupun ada dari beberapa siswa yang masih kurang disiplin dalam menjalankan tata tertib dan kebijakan kepala sekolah tersebut.

Kegiatan dengan kedisiplinan guru pada dasarnya lebih berfokus pada prilaku tenaga pengajar di dalam pekerjaannya, demikian pula prihal efektifitas guru adalah sejauh mana kinerja tersebut dapat memberikan pengaruh kepada siswa. Karena secara spesifik tujuan disiplin juga mengharuskan guru membuat keputusan khusus di mana tujuan pengajaran dinyatakan dengan jelas dalam bentuk tingkah laku yang kemudian ditransferkan pada siswa.

Langkah yang dilakukan oleh kepala sekolah SMP Islam Plus Darul Hukumaini Jonggat untuk meningkatkan kedisiplinan guru dengan beberapa tahap. Pertama; membuat aturan, tata tertib. kedua; membuat prosedur kegiatan, menetapkan jam kegiatan dan petugasnya, menempatkan guru pada bidang sesuai dengan latar belakang mereka, membuat kegiatan yang meningkatkan keterampilan siswa dan yang memiliki efek menambah pengetahuan agama dan keislaman siswa, serta memberikan motivasi dan teladan yang baik bagi warga sekolah.

Dapat disimpulkan bahwa peran kepala sekolah SMP Islam Plus Darul Hukumaini Jonggat dalam meningkatkan kedisiplinan guru sudah cukup baik dan terkonsep dengan jelas. Langkah yang dilakukan oleh kepala sekolah dalam meningkatkan kinerja guru merupakan bentuk upaya Preventif (pencegahan sebelum terjadi masalah) (Atmaja, 2015: 153).

Permasalahan kedisiplinan guru pada masa Covid-19 biasanya tampak jelas dari menurunnya ketaatan warga sekolah pada protokol kesehatan dan kebijakan lembaga pendidikan. Salah satu permasalah yang terjadi adalah sulitnya membentuk kedisiplinan warga sekolah. Faktor yang sangat mendukung kedisiplinan di SMP Islam Plus Darul Hukumaini Jonggat adalah; 1) Guru yang terlalu sulit diatur, 2) Peraturan yang masih dijaga dan dipegang oleh personil sekolah, 3) Siswa yang tunduk dan tidak banyak berontak atau melawan. Dan hal yang paling penting dalam membentuk kedisiplinan adalah teamwork (kerjasama) antara semua unsur yang ada dalam sekolah karena hal tersebut sangat membantu dalam meningkatkan kedisiplinan di SMP Islam Plus Darul Hukumaini Jonggat.

Faktor lain yang mendukung kedisiplinan guru adalah sarana prasarana yang dimiliki oleh sekolah, pematuhan protokol kesehatan secara ketat, peraturan yang sudah pasti dan akuntabel, pengelola yang tegas, kebijakan kepala sekolah, lingkungan sekolah yang kondusif, dukungan warga yang tinggi, dukungan dari wali murid. Semua faktor diatas dapat memudahkan kepala sekolah dalam meningkatkan kedisiplinan di SMP IP Darul Hukumaini Jonggat. Dukungan dari wali murid serta warga lingkungan sekolah merupakan hal yang sangat penting dalam membangun sekolah yang disiplin.

Peranan kepala sekolah dalam meningkatkan disiplin kinerja guru Pada Masa Covid19 di SMP Islam Plus Darul Hukumaini Jonggat yaitu Setiap kepala sekolah harus mampu 
menjadi pendorong dan motivator bagi bawahannya, agar tercipta situasi dan kondisi belajar yang efektif terlebih pada masa-masa sekarang ini. Berdasarkan pendapat di atas seorang kepala sekolah sangat dituntut untuk mempengaruhi guru untuk melaksanakan tugastugasnya secara profesional.

Sikap kepemimpinan seorang kepala sekolah dalam menjalankan dan menggerakkan guru sesuai dengan mekanisme dan aturan yang berlaku tanpa ada intimidasi ataupun tekanan akan sangat mempengaruhi seorang guru dalam menjalankan tugas-tugasnya dengan disiplin dan rajin serta menjadi teladan siswa siswinya disekolah. Dan sebaliknya, jika seorang kepala sekolah dalam menjalankan dan menggerakkan guru tidak sesuai dengan aturan dan mekanisme yang berlaku tanpa memperhatikan asas kebijaksanaan, maka dipastikan guru tersebut akan tertekan dan tidak akan profesional.

Adapun uraian mengenai Langkah-langkah yang ditempuh oleh kepala sekolah SMP Islam Plus Darul Hukumaini Jonggat dalam meningkatkan kedisiplinan kinerja guru Pada Masa Covid-19 yaitu dengan langkah Preventif: langkah ini untuk mencegah tingkah laku guru dan siswa yang dapat mengurangi kedisiplinan dalam menjalankan tugas-tugasnya. Langkah ini mempunyai 4 strategi, yaitu: pertama; Membuat aturan dan tata tertib dan menjalankannya sesuai hasil keputusan bersama. Kepala sekolah SMP Islam Plus Darul Hukumaini Jonggat mempunyai aturan atau tata tertib sekolah yang harus dijalankan oleh warga sekolah, dengan aturan tersebut kepala sekolah berharap semua jenis pelanggaran yang bisa terjadi bisa berkurang seperti pematuhan protokol kesehatan.

Kedua; Membuat prosedur dan kebiasaan-kebiasaan sehari-hari sesuai aturan. Sekolah SMP Islam Plus Darul Hukumaini Jonggat juga membuat sebuah prosedur dalam setiap unit kegiatan yang ada di sekolah, seperti prosedur aturan, prosedur administrasi sekolah, dan prosedur konsling oleh guru yang berwenang. Dengan prosedur tersebut semua unit didalam naungan sekolah tidak memiliki wewenang untuk melakukan setiap kegiatan diluar aturan dan prosedur sekolah, sehingga semua kegiatan sekolah baik itu guru maupun siswa akan bisa dimonitoring oleh kepala sekolah dan selalu bisa diawas. Ketiga; Menyiapkan kurikulum sekolah yang tepat sesuai dengan kemampuan dan keahlian guru. Bagi guru-guru SMP Islam Plus Darul Hukumaini Jonggat sebagian besar sudah ditempatkan pada bidang yang tepat sesuai dengan latar belakang pendidikan mereka. Cara ini untuk mengurangi hambatan dalam kelas dan proses pembelajaran. Langkah ini merupakan solusi awal Untuk mengantisipasi kesulitan belajar didalam kelas.

Keempat; Meningkatkan keprofesionalan kerja kepala sekolah, agar guru dapat termotivasi untuk berprestasi dalam bekerja. Kepala sekolah SMP Islam Plus Darul Hukumaini Jonggat sudah berusah untuk meningkatkan profesionalisme dalam menjalani tugas sebagai kepala sekolah, yakni menjalani semua kompetensi yang harus dimiliki oleh kepala sekolah, selain menjadi guru, kepala sekolah juga menjadi manager, motivator, educator, supervisor di sekolah.

\section{Kendala yang dihadapi dalam meningkatkan kinerja guru di SMP Islam Plus Darul Hukumaini Jonggat}

Banyak kendala yang dihadapi oleh kepala sekolah SMP Islam Plus darul Hukumaini Jonggat dalam meningkatkan kinerja guru dan. Salah satunya adalah fasilitas sekolah yang kurang memadai seperti media yang digunakan untuk mengajar seperti alat peraga, LCD, dan buku LKS untuk siswa, itu semua membuat waktu mengajar menjadi membengkak dan waktu mengajar sering mundur, sehingga guru mengambil jam pelajaran guru lain bahkan memotong waktu istirahat siswa. 
Kepala sekolah SMP Islam Plus Darul Hukumaini Jonggat dalam melaksanakan perannya mendapatkan hambatan yaitu kurangnya disiplin guru dalam hal jadwal pelajaran yang telah ditentukan sekolah, karena masih ada guru yang menjemput anaknya sekolah dan meninggalkan pelajaran yang telak dilaksanakan di sekolah, selain itu ada juga guru yang membawa anaknya ke sekolah sehingga dapat mengganggu waktu mengajar guru tersebut. Dalam mengatasi hal ini kepala sekolah telah menegur dengan lisan tetapi masih ada juga guru yang mengulanginya dengan alasan anaknya sendirian di rumah.

Kepala sekolah juga mendapatkan hambatan dalam hal saran dan prasarana yang masih kurang di SMP Islam Plus Darul Hukumaini Jonggat karena melihat keberhasilan program pendidikan melalui proses belajar mengajar sangat dipengaruhi oleh banyak faktor, salah satu di antaranya adalah tersedianya sarana dan prasarana pendidikan yang memadai disertai pemanfaatan dan pengelolaan secara optimal. Sarana dan prasarana pendidikan merupakan salah satu sumber daya yang penting dan utama dalam menunjang proses pembelajaran di sekolah, untuk itu perlu dilakukan peningkatan dalam pendayagunaan dan pengelolaannya.

Kurangnya sarana dan prasarana yang di miliki SMP Islam Plus Darul Hukumaini Jonggat antara lain media yang belum memenuhi kebutuhan yang diperlukan sekolah sehingga sekolah membutuhkan waktu yang cukup lama untuk menjelaskan materi yang membutuhkan contoh lansung, kurangnya buku pelajaran/buku bacaan yang masih kurang di perpustakaan dan belum adanya Unit Kesehatan Sekolah (UKS), ini menjadi tugas kepala sekolah yang tidak kalah penting untuk memenuhinya. Dari keterangan kepala sekolah diatas, bahwa upaya kepala sekolah dalam meningkatkan kedisiplinan guru dan siswa dengan menghimbau dan memberikan motivasi agar guru tidak mengeluh dan tetap menjalankan tugas dengan semsetinya. Sedangkan dalam manangani pelanggaran yang terjadi, kepala sekolah memberikan hukuman kepada guru maupun siswa agar berhenti dan tidak mengulangi pelanggaran yang pernah dilakukannya.

Kedisiplinan dan Kinerja guru terbentuk oleh kesadaran guru itu sendiri, namun untuk meningkatkan kesadaran para guru tersebut dibutuhkan motivasi dari kepala sekolah, sehingga guru di SMP Islam Darul Hukumaini Jonggat selalu diberikan motivasi oleh kepala sekolah dalam bentuk arahan dan teladan yang baik untuk selalu disiplin dan rajin untuk mengajar dikelas. Kepala sekolah hanya bisa memberikan arana dan contoh bagi para guru dan selebihnya dari kepala sekolah mengharapkan kesadaran dari setiap guru-guru dan siswa untuk tetap menjaga kedisiplinan didalam sekolah.

\section{KESIMPULAN}

Peran kepala sekolah dalam meningkatkan kinerja guru dilakukan dengan cara membuat aturan dan tata tertib dan menjalankannya sehari-hari sesuai hasil keputusan bersama, membuat prosedur dan kebiasaan-kebiasaan sehari-hari sesuai dengan protokol kesehatan, menyiapkan kurikulum sekolah yang tepat sesuai dengan kemampuan dan keahlian guru dan meningkatkan keprofesional kerja kepala sekolah agar guru dapat termotivasi untuk berprestasi dalam bekerja.

Faktor pendukung dalam meningkatkan kinerja guru dan siswa di SMP Islam Plus Darul Hukumaini Jonggat adalah sarana dan prasarana, pematuhan protokol kesehatan, peraturan yang ada, pengelolaan yang tegas, dan kebijakan sekolah, sedangkan faktor ekstern seperti lingkungan yang kondusif, dukungan masyarakat dan wali murid, sedangkan yang menjadi faktor yang mpenghambat kepala sekolah seperti kurangnya disiplin guru dalam hal jadwal pelajaran, kurangnya sarana dan prasarana dan solusi terhadap kepala sekolah dengan memberikan motivasi bagi setiap guru dan siswa untuk tetap menjaga 
kedisiplinan di sekolah dan menanamkan kesadaran diri dalam menjaga kedisilinan, memberikan sangsi bagi yang melanggar peraturan baik itu guru maupun siswa.

\section{DAFTAR PUSTAKA}

Aji, R. H. S. (2020). Dampak Covid-19 pada Pendidikan di Indonesia: Sekolah, Keterampilan, dan Proses Pembelajaran. SALAM: Jurnal Sosial Dan Budaya Syar-i, 7(5), 395402. https://doi.org/10.15408/sjsbs.v7i5.15314

Anas purwantoro, "Upaya Sekolah Dalam Meningkatkan Kedisiplinan Siswa MTSN Ngemplak, Sleman, Yogyakarta", dalam http://library.um.ac.id/ ptk/index.phpmod=detail\&id=40938

Amalia, A., \& Sa'adah, N. (2021). DAMPAK WABAH COVID-19 TERHADAP KEGIATAN BELAJAR MENGAJAR DI INDONESIA. Jurnal Psikologi, 13(2), 214-225. https://doi.org/10.35760/psi.2020.v13i2.3572

Andriyani, S. (2013). Peran kepemimpinan kepala sekolah dalam menumbuhkan kedisiplinan guru dan karyawan di SMK Negeri 1 Surakarta. https://digilib.uns.ac.id/dokumen/30670/Peran-kepemimpinan-kepala-sekolahdalam-menumbuhkan-kedisiplinan-guru-dan-karyawan-di-SMK-Negeri-1-Surakarta

Devi, R. S., Sulistiani, I. R., \& Sulistiono, M. (2019). Upaya Kepala Sekolah Dalam Pembinaan Kedisiplinan Bagi Peserta Didik di SMP Islam Al Ma'arif 02 Malang. Vicratina: Jurnal Pendidikan Islam, 4(6), 124-132.

Fitrah, M. (2017). PERAN KEPALA SEKOLAH DALAM MENINGKATKAN MUTU PENDIDIKAN. Jurnal Penjaminan Mutu, 3(1), 31-42. https://doi.org/10.25078/jpm.v3i1.90

Gaol, N. T. L., \& Siburian, P. (2018). Peran Kepala Sekolah Dalam Meningkatkan Kinerja Guru. Kelola: Jurnal Manajemen Pendidikan, 5(1), 66-73. https://doi.org/10.24246/j.jk.2018.v5.i1.p66-73

Juliana, (2014) Upaya Kepala Sekolah Sebagai Supervisor dalam Meningkatkan Mutu Pembelajaran pada Bidang Studi IPS Ekonomi, Skripsi, IAIN Mataram, Mataram,.

Kusuma, Atmajaya, "Peran Seorang Kepala Sekolah di Dalam Meningkatkan Kedisiplinan dan Kerajinan Guru Bantunya di Sekolah Dasar", Dalam http//one.indoskripsi.com.

Mulyasa, Kurikulum Berbasis Kompetensi Konsep, Karakteristik dan Implementasi), Bandung : Remaja Rosda Karya, 2006.

Nashir, A. (2016). PENGARUH KEDISIPLINAN GURU TERHADAP PRESTASI BELAJAR. TARBAWI: Jurnal Pendidikan Agama Islam, 1(1), 21-28. https://doi.org/10.26618/jtw.v1i1.349

Sri Purwanti, (2013) Peran Kepemimpinan Kepala Sekolah dalam Meningkatkan Disiplin Kerja Guru dan Pegawai Di SMA Bakti Sejahtera Kecamatan Kongbeng Kabupaten Kutai Timur Ejournal administrasi negara, 210-224. 
Sugiyono. (2009). Metode penelitian pendidikan: (Pendekatan kuantitatif, kualitatif dan $R$ \& D). Alfabeta.

Sumbana dan Sudrajat, (2005), Dasar-dasar Penelitian IImiah, Bandung :CV Pustaka Setia

Uriatman, M. (2015). Upaya Kepala Sekolah dalam Meningkatkan Kedisiplinan Guru. Manajer Pendidikan, 9(6), 270940.

Yani, H. (2014). Peran Kepemimpinan Kepala Sekolah dalam Pembiasaan Beragama dan Berbudi Pekerti Siswa. MUDARRISA: Jurnal Kajian Pendidikan Islam, 6(2), 168193. https://doi.org/10.18326/mdr.v6i2.168-193

Yuliandri, J., \& Kristiawan, M. (2017). PERAN KEPEMIMPINAN KEPALA SEKOLAH TERHADAP PENINGKATAN KINERJA GURU. Jurnal Dosen Universitas PGRI Palembang, $\quad 0, \quad$ Article $\quad 0 . \quad$ https://jurnal.univpgripalembang.ac.id/index.php/prosiding/article/view/1057 